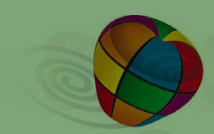

SKOLKOVO

\title{
Political Feasibility of
}

\section{Enhancing the Russian}

Emissions Reduction Target

Under the Paris Agreement

Imtenan Al-Mubarak, Saleh Al Muhanna and Zlata Sergeeva 


\section{About KAPSARC}

The King Abdullah Petroleum Studies and Research Center (KAPSARC) is a non-profit global institution dedicated to independent research into energy economics, policy, technology and the environment across all types of energy. KAPSARC's mandate is to advance the understanding of energy challenges and opportunities facing the world today and tomorrow, through unbiased, independent, and high-caliber research for the benefit of society. KAPSARC is located in Riyadh, Saudi Arabia.

This publication is also available in Arabic.

\section{Legal Notice}

(C) Copyright 2019 King Abdullah Petroleum Studies and Research Center ("KAPSARC"). This Document (and any information, data or materials contained therein) (the "Document") shall not be used without the proper attribution to KAPSARC. The Document shall not be reproduced, in whole or in part, without the written permission of KAPSARC. KAPSARC makes no warranty, representation or undertaking whether expressed or implied, nor does it assume any legal liability, whether direct or indirect, or responsibility for the accuracy, completeness, or usefulness of any information that is contained in the Document. Nothing in the Document constitutes or shall be implied to constitute advice, recommendation or option. The views and opinions expressed in this publication are those of the authors and do not necessarily reflect the official views or position of KAPSARC. 


\section{Key Points}

$t$ is widely recognized that the commitments set out in the Paris Agreement fall short of achieving the 2 degrees Celsius global warming target, agreed as the central goal of the agreement and its parties.

Given this, KAPSARC has set out to explore the political feasibility of enhancing nationally determined contributions by utilizing the KAPSARC Toolkit for Behavioral Analysis (KTAB). This paper investigates the Russian case. Key insights include:

The collapse of the Soviet Union and Russia's shift away from Soviet-style industrial production dramatically reduced emissions, currently around $70 \%$ of 1990 levels.

With the Russian intended nationally determined contribution (INDC) set to limit anthropogenic greenhouse gas (GHG) emissions to $70-75 \%$ of 1990 levels, it is consequently not considered a problem for Russia to meet its target by 2030 . Indeed, Russia may even increase emissions while still meeting its 2030 target.

Russia continues to stress that its extensive forests provide a large contribution to capturing carbon that benefits the rest of Europe.

Russia has little incentive to formulate a more ambitious set of climate goals. The general feeling is that Russia has done its part for the environment and that the rest of the world needs to catch up.

The simulation methodology presented in this paper suggests that there is little momentum for Russia to meaningfully enhance its commitments to reduce emissions. 


\section{Executive Summary}

$\mathrm{T}$ The Russian Federation is one of the world's top five carbon emitters, along with China, the United States, India and the European Union. While Russia was among the initial 175 signatories to the Paris Agreement, the country has not yet ratified it.

Russia has already experienced a significant reduction in emissions with the fall of the Soviet Union, an argument it frequently utilizes despite the fact that environmental considerations were not a motivating factor. The reduction in Russia's emissions was a direct result of the dissolution of the Soviet Union in 1991 and the subsequent economic slump that led to the collapse of its industrial sectors. Russian negotiators also repeatedly emphasize the importance of their forests, which account for approximately $19 \%$ of global forest reserves, and the positive impact they have on the remainder of the European continent by acting as a carbon sink.

These two arguments, in addition to the lack of an economic incentive, help illustrate the Russian point of view with regard to climate change mitigation: Russia has already done its part for the environment and the rest of the world needs to catch up. However, Russia has been criticized for its unambitious target, with its base year being set prior to the collapse of the Soviet Union.
Estimates have shown that current Russian policies will lead to an increase in average annual Russian emissions, excluding land use, land-use change and forestry (LULUCF), of 2.65 gigatonnes of carbon dioxide equivalent (GtCO2e) in 2020, rising to 2.9 GtCO2e in 2030 (Figure 1). These levels reveal a significant decrease in annual emissions when compared with 1990 levels: down by $27-29 \%$ in 2020 and by $20-25 \%$ in 2030. 1990 is the base year for the Russian INDC target. This indicates that Russia can not only easily meet its INDC target, but can also afford to increase emissions without jeopardizing its contribution.

This study assesses the political feasibility of advocating more ambitious emission reduction targets amongst Russian stakeholders. It uses KTAB to simulate collective decision-making processes to assess the expected level of support for, and reaction to, a more ambitious Russian INDC. The results of the model simulation suggest that within the current political context, it is not politically feasible to adopt policies that would enhance Russia's emissions reduction commitments. Results also suggest that this issue is not of particular importance to the Russian leadership, further decreasing the likelihood of a more ambitious target. 


\section{Introduction}

W

hile the Russian Federation was among the 175 initial signatories to the Paris

Agreement in 2016, the country has yet to ratify it. Government officials have stated that Russia is not intentionally delaying ratifying the agreement, but is instead in the process of careful preparation. There is currently widespread speculation regarding the date of possible ratification.

The Russian INDC includes a target to limit greenhouse gas (GHG) emissions to $70 \%$ of 1990 levels by 2030, a level higher than actual emissions in Russia for the past 20 years. Indeed, this fact is reflected in statements by the Russian Deputy Prime Minister, Alexander Khloponin, that the country "has countervailed emission growth in other states and regions to a significant degree" (RussiaUN 2016). Khloponin also claimed that countervailing this growth is "an illustrative confirmation of Russia's leading role in the international climate process" (RussiaUN 2016). This is the context in which plans are being developed, such as a national adaptation plan aimed at the sustainable management of forests and a long-term 2050 low-carbon development strategy, alluding to an increased focus on reducing emissions.

This study applies the KAPSARC Toolkit for Behavioral Analysis (KTAB), a model of collective decision-making processes (CDMPs), to conduct an analysis of Russian stakeholders. It offers insight into support for further ambitions to reduce Russia's emissions and possible enhancement of its INDC under the United Nations Framework Convention on Climate Change (UNFCCC). 


\section{Fall of the Soviet Union and Subsequent Decarbonization}

$\mathbf{R}$ ussia significantly reduced its levels of emissions with the fall of the Soviet Union in

1991. The Soviet collapse led to an economic meltdown, with gross domestic product falling by about $40 \%$ over the remainder of the decade (Aslund 1999). The economic collapse led to a sharp decrease in industrial production and activity, and with that, a significant reduction in GHG emissions. It has been estimated that GHG emissions in the country fell by an astonishing 51\% between 1990 and 2008 (Howarth and Foxall 2012). While that amount of decarbonization may have been an unintentional consequence, it has served Russia well in climate negotiations in the years since.
Amongst the main criticisms aimed at Russia regarding climate is the country's unambitious reduction targets, with respect to both the Kyoto Protocol and the Paris Agreement. The targets in both instances were not only achievable with minimal effort, but they also allowed the country to continue to increase its emissions without facing the threat of missing its targets, as shown in Figure 1. Setting the targets' base year to 1990 ensures Russia is nominally far ahead of other countries in terms of decarbonization.

Figure 1. Russian historical and projected emissions based on current policies (1990-2030).

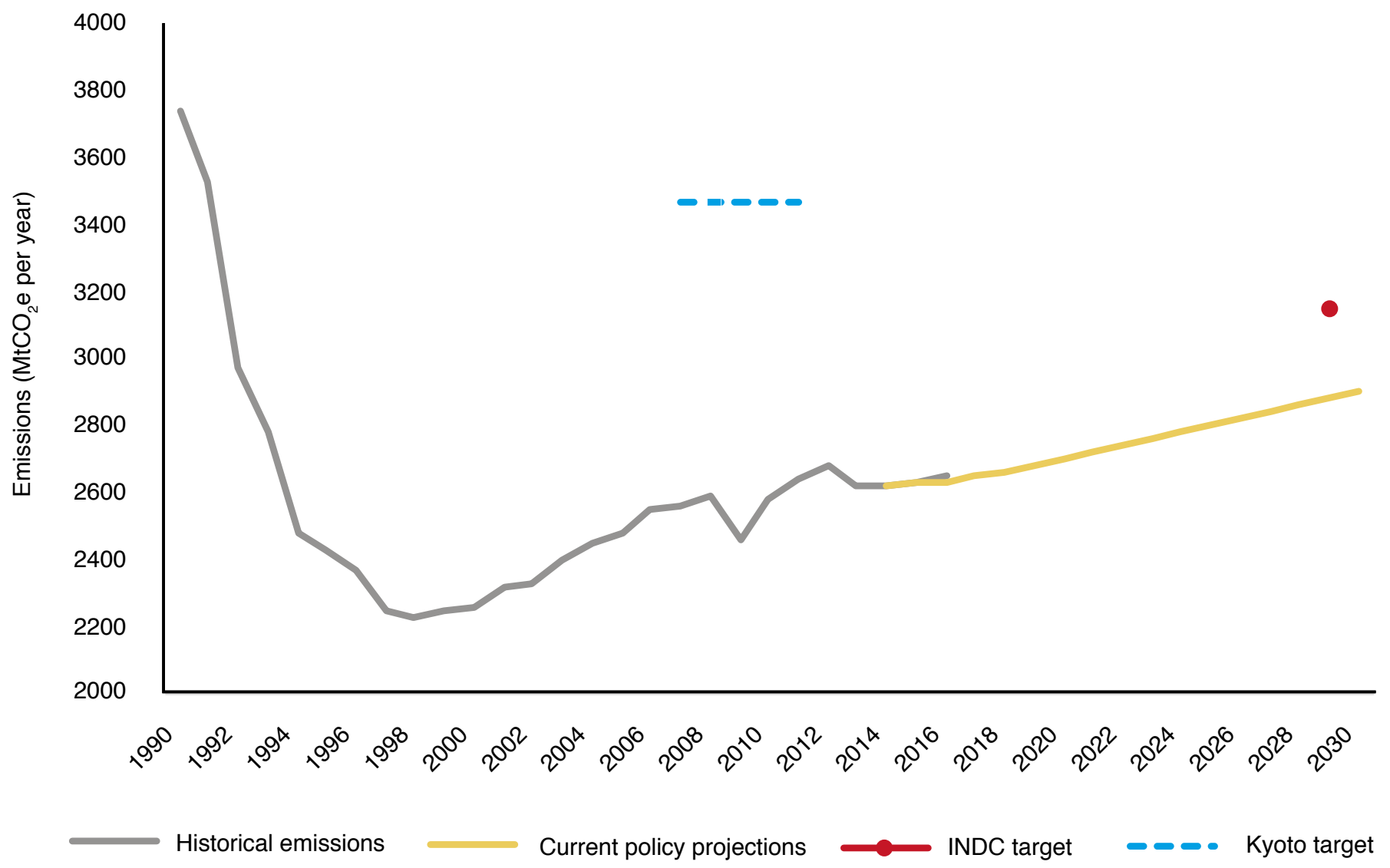




\section{Previous Russian Experience}

ussia has previous experience participating in international climate agreements, notably the Kyoto Protocol. Similar to the Paris Agreement, the process of ratifying and applying the Kyoto Protocol in Russia was protracted and extended with various delays. Initially signed in March 1999, it took more than five years for the protocol to be ultimately ratified in Russia. However, Russia is often credited with saving the protocol, as it required ratification by 55 industrialized nations that represented at least 55\% of $1990 \mathrm{GHG}$ emissions. Prior to Russian ratification, countries representing only $44 \%$ of worldwide GHG emissions had ratified the agreement. With the United States (U.S.) and Australia refusing to participate, this meant that Russian ratification ensured the protocol's political survival. By 2010, Russian emissions were 34\% below 1990 levels, far below their Kyoto target (Astrasheuskaya 2012).
There are two main interpretations of Russia's lingering approach toward the Kyoto Protocol. According to the experts interviewed for this study, one explanation was the lack of a clear understanding among Russian officials of its possible economic consequences, with some Russian officials describing it in unflattering terms. Alternatively, the late ratification could have been an attempt to gain a political advantage (particularly following the U.S. decision not to ratify) to increase Russian bargaining power in the international arena.

Indeed, ratification of the Kyoto Protocol was viewed as a purely political measure by many observers, as President Putin announced Russia's intention to ratify on the same day that the European Union ceased its objections to Russian accession to the World Trade Organization. The protocol was ratified in Russia in November 2004 and came into effect 90 days later. 


\section{Reaction to the Paris Agreement}

urning to the Paris Agreement, while Russia has set its INDC, the country has yet to ratify the agreement. It has become clear from ministerial meetings that Russian authorities, including the Ministry of Natural Resources, have no interest in rushing the ratification process. Indeed, the prevailing position of Russian officials was to seek ratification after the agreement's procedures were finalized during the 24th Conference of the Parties in Katowice in late 2018, although this position did not hold. It was later revealed by Sergei Ivanov, the Special Representative of the President on Environmental Activities, in March 2019 that Russia would ratify the agreement "only after full accounting of forests and their ability to absorb CO2" (RIA Novosti 2019). The head of the Russian Federal Forestry Agency, Ivan Valentik, has stated that the stocktaking of forests should be completed by 2020 .

Currently, the most preferred Russian mechanism for meeting its commitments under the Paris Agreement is to continue supporting projects targeted at GHG emissions reductions and increasing energy efficiency through tax cuts, tax credits and reduction factors for equipment depreciation. Russian authorities are also developing rules for GHG offset mechanisms, mainly forest projects for companies, as discussions surrounding methods of calculating absorbed emissions are still ongoing.
More ambitious modification of the Russian target has not been the focus of debate. The draft of the federal law titled "On the Regulation of Greenhouse Gas Emissions" suggested limiting GHG emissions to no more than $75 \%$ of 1990 levels and rapidly received public criticism. As stated in a letter by the Russian Union of Industrialists and Entrepreneurs (RSPP) in April 2018, Russia's emissions level already amounted to $70 \%$ of 1990 levels when accounting for forest absorption. The Ministry of Economy had also openly stated that Russia's assumed levels of obligation would mean that firm restrictions on GHG emissions need not be enforced. Measures such as carbon pricing or the creation of an emissions permits market were not under serious consideration.

However, in December 2018, the Ministry of Economic Development proposed new draft legislation titled "Federal Law on State Regulation of Emissions and Absorption of Greenhouse Gases and on Amending Selected Legislative Acts of the Russian Federation." The legislation as drafted proposes giving the government power to identify which GHGs will be subject to regulation, and to establish limits on emissions and the issuance of GHG emission permits, as well as setting fees for GHG emissions. The bill is facing considerable opposition and is yet to be passed.

We now turn to an assessment, using the KTAB methodology, of the political feasibility of implementing an increasingly ambitious Russian INDC. 


\section{KTAB and the Spatial Model of Politics}

TAB is a platform that enables the modeling and analysis of CDMPs. CDMPs capture

the political bargaining process, both explicit and implicit, among a set of actors - which can include individuals, institutions, constituencies and identifiable groups or 'blocs.'

In this paper we present an analysis of plausible outcomes for CDMPs relating to Russia's INDC. We used a specific instantiation of a model in KTAB, based on the Spatial Model of Politics (SMP), one of the most prominent and best-established models of CDMPs. The SMP simulates how actors interact with and influence one another over time to arrive at a 'feasible outcome' for the modeled question. This reflects a model-based view of the expected outcome for actors' collective support for - or opposition to - enhancing the Russian INDC.
Aggregate knowledge of the experts characterizes the current political landscape (referred to as turn 0), but all simulations beyond turn 0 are based purely on the KTAB SMP calculations.

We have chosen to focus on analytical results. For a detailed technical description of the underlying model and its calculations, interested readers are referred to Wise, Lester, and Efird (2015a) and Wise, Lester, and Efird (2015b).

Both papers are freely available from KAPSARC's website and the KTAB portal, as is the program's source code and documentation. Please visit www. ktab.software for all related papers, the latest version of the software and all materials of interest related to $K T A B$. 


\section{Defining the Question}

Then using the KTAB methodology to analyze a CDMP, the first step is to define the modeled question. In this paper, we are evaluating the disposition of key stakeholders on the issue of enhancing the Russian INDC. This type of question lends itself well to a linear scale that can capture a range of potential support for or opposition to this issue, as shown in Figure 2.

The spectrum depicted in Figure 2 provides the range of positions that actors can take regarding the issue. For example, actors assigned a position at or close to 50 are perceived as neutral toward the notion of implementing more ambitious carbon reducing targets. Actors holding a position of 100 are seen as fully supportive of the issue, while actors holding a position of 0 are fully opposed. Positions ranging from 0 to 50 reflect increasing opposition, and positions ranging from 50 to 100 reflect increasing support, with the degree of opposition or support dependent on the distance between an actor's position and the two extremes on the scale.

Figure 2. Spectrum of positions: Range of actors' advocacy opposed to or supportive of enhancing Russia's INDC.

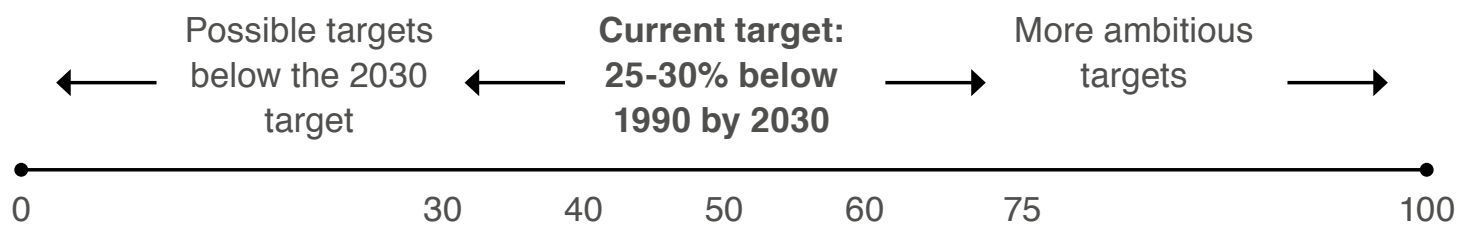

Source: KAPSARC. 


\section{The KTAB SMP Data Inputs}

D ata for the KTAB SMP model were obtained through semi-structured interviews with subject matter experts. Interviews were conducted with the explicit agreement not to attribute specific answers to any particular expert. Moreover, experts were also given the opportunity to keep their contribution completely anonymous. Seven subject matter experts were interviewed in Moscow, Russia, from July 15 to 19,2018 . The names and qualifications of experts interviewed are listed below (all elected to be named in this list):

Alexey Kokorin, Director of Climate and Energy Program, WWF Russia (a leading Russian expert in the area of climate and energy transitions).

Igor Makarov, Senior Researcher, Higher School of Economics, National Research University (a leading Russian expert in the area of climate and energy transitions).

Michail Yulkin, Director of the Center for Energy Investments (a leading Russian expert in the area of climate and energy transitions).

Vladimir Sidorovich, Director General, Institute of Energy Efficient Technologies in Construction (one of the most prominent Russian experts on clean technologies).

Vitaly Yermakov, Head of the Center for Energy Policy Research, Higher School of Economics, National Research University.

Vladimir Chouprov, Head of the Energy Program, Greenpeace Russia.

Alexey Kainin, SKOLKOVO, Moscow School of Business.
It is important to emphasize that interviewed experts only provided the numerical values described in this section and that this paper does not represent their views or conclusions.

In consultation with the experts, we identified a comprehensive list of actors, including policymakers, stakeholders and influencers, and obtained three specific quantitative attributes for each actor during the interviews. Those attributes are defined as:

Position: the location of an actor on the linear spectrum. In other words, what is the actor's advocacy concerning support for, or opposition to, enhancing the Russian INDC?

Influence: the relative overall degree of political power, or clout, of each actor. The most powerful actor is assigned a value of 100 , and other actors are weighted relative to the most powerful actor.

Salience: the relative priority each actor assigns to the modeled questioned as compared with other issues that compete for the actor's attention.

The expert data collected were then aggregated into a single dataset, hereafter referred to as the baseline dataset. The full dataset is detailed in Table 1 of the Appendix. This table represents stakeholder data, utilizing the collective knowledge of the relevant actors, as determined by the seven experts interviewed, who also assigned values to an actor's position, influence and salience. "Exercised power" is simply the product of influence and salience divided by 100 , and indicates the amount of influence an actor is willing to apply to the modeled issue. 


\section{Simulation Results}

$\mathrm{n}$ this section, we present our analysis of the simulation results for the baseline dataset, i.e., the weighted average of the expert data. A visualization of the baseline dataset and the final simulation results are presented in Figure 3, below. The left-hand side of the figure is a representation only of the experts' data, which describe the current landscape of actor positions and exercised power before simulating the negotiating process (turn 0 ). Meanwhile, the right-hand side presents the same landscape following the conclusion of the simulated negotiating process. Expert input ends after providing data for turn 0 . In this case, the simulation ran for 19 negotiating turns (or rounds), reflecting a protracted and lengthy debate. During these turns actors bargained with one another in an attempt to achieve their preferred outcomes. The model continues to iterate negotiating rounds until there is a minimal change in actor positions, reaching a 'steady state' where additional turns would not appreciably change the result.

In each of the graphs in Figure 3, the horizontal axis replicates the position spectrum described in Figure 2, and the vertical axis represents the exercised power for each actor (calculated from an actor's influence and salience). Each of the bars in the figure represents a specific actor, and actors are color-coded according to the figure's key. The height of each bar mirrors the actor's exercised power.

Note that many of the actors are stacked on top of each other - this indicates that they hold the same position (within roughly a five-point range). Thus, the overall height of the 'stack' of bars depicts the exercised power from those in a coalition advocating a particular position.

Figure 3. Comparison between turn 0 and turn 19 distribution of positions and exercised power.

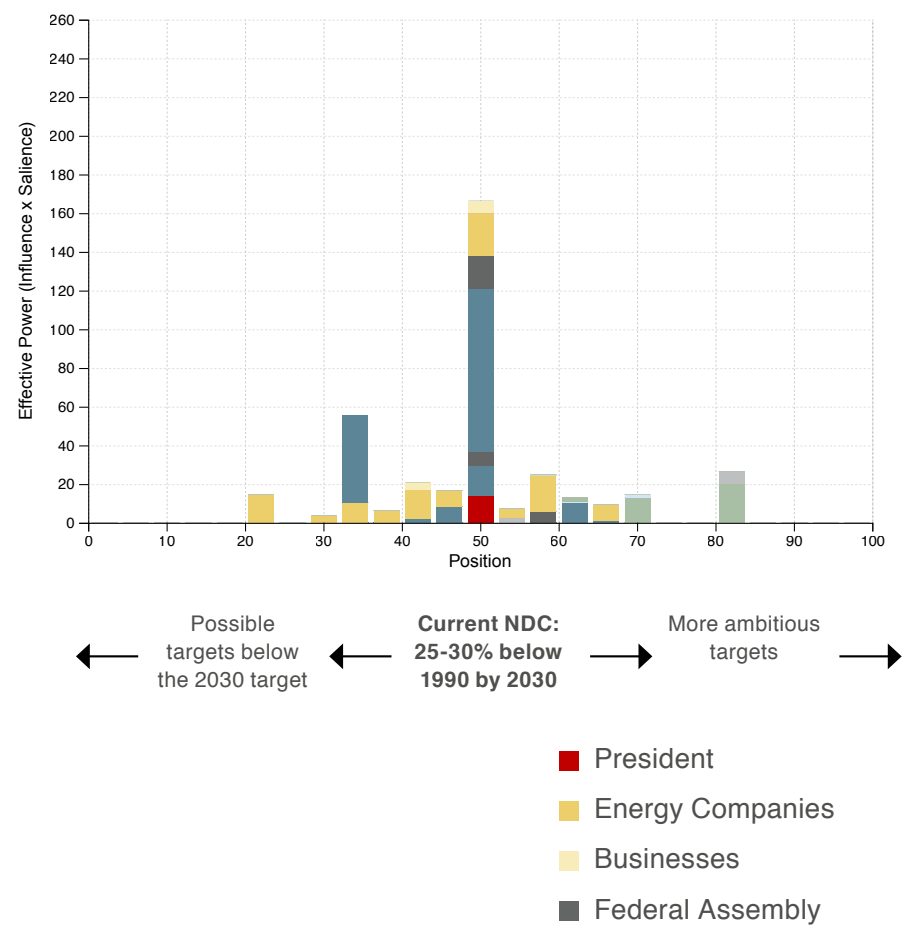

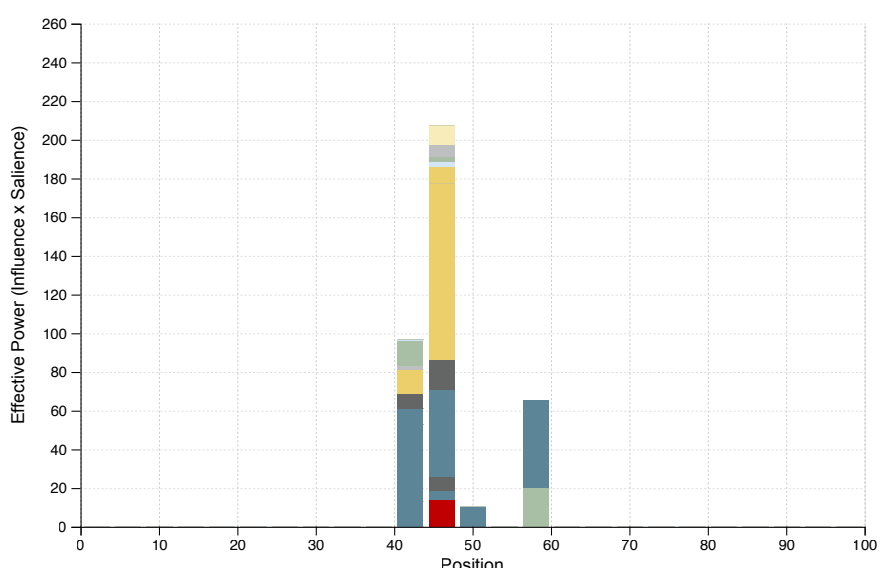

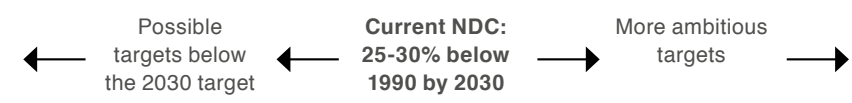

Executive Branch

Climate Organizations

Renewable Energy Companies

International Companies

Source: KAPSARC KTAB analysis. 
Based on the expert input depicted in Figure 3, President Putin (the red bar), in addition to other government officials and energy companies, appears indifferent to amending Russia's current targets. Putin is clearly the final decision-maker in Russia, yet his lack of interest in the subject provides other actors with the opportunity to help shape his views on the issue. Sergei Ivanov is seen to strategically position himself conservatively, with the intention of providing room for political maneuvering in order to ultimately maintain the status quo and persuade other actors to align with the president's position.

Gazprom, one of the world's largest natural gas producers, adopts a neutral position, indicating that the company sees opportunities for financial benefit from various outcomes on this issue with little downside. For example, a Russian switch from coal to gas, if the negotiations lead to enhanced environmental targets, would be beneficial for Gazprom. However, holding a neutral position gives the impression that Gazprom is maintaining the status quo, and it would not be adversely affected if the negotiations lead to unchanged climate targets.

Toward one side of the spectrum, SUEK, one of the world's largest coal companies and a strong advocate against climate change accommodation in Russia, adopts an extremely negative position on enhancing the INDC. SUEK is known for having a long history of lobbying against policies that favor low-carbon fuels. Toward the other side, Rusal, the world's largest aluminum producer, is already planning to meet $100 \%$ of its power needs from clean energy sources by 2020 . The company anticipates an economic gain from supporting the issue as it has lower-cost smelters run on hydroelectric power sources. Oleg Deripaska, the owner of Rusal and one of Russia's richest oligarchs, is a very active proponent for climate action in Russia, yet his influence has severely decreased following U.S. sanctions placed on his companies and his personal assets. He has recently dissociated himself from Rusal in an attempt to shield the company from sanctions. Rusnano, a state-owned tech company active in promoting renewable energy, and Rosatom, a state-owned nuclear energy company that is also the largest electricity generating company in Russia, hold a position very supportive of more ambitious targets for Russia.

By the end of the simulation, as shown on the right-hand side of Figure 3, consensus builds around maintaining the current INDC, indicating that the majority of actors agree that the current target need not be meaningfully adjusted. During the simulation, coal companies, led by SUEK, actively lobbied for even less ambitious climate goals, but they were ultimately not resistant to the final consensus as it reflects business as usual and would not significantly affect their business. By the end of the simulation, the position of the RSPP indicates that the organization acknowledges climate change should be addressed, but Russian companies are not currently ready to do so given Russia's economic stagnation, in addition to U.S. sanctions targeting Russia. Thus, they join the consensus of maintaining the current targets. The two actors that stray from the consensus, Ivanov and Rosatom, are only advocating a slightly more ambitious target - indicating that they are unlikely to object to the achieved consensus. 
Figure 4. Simulated change in actor positions, by turn.

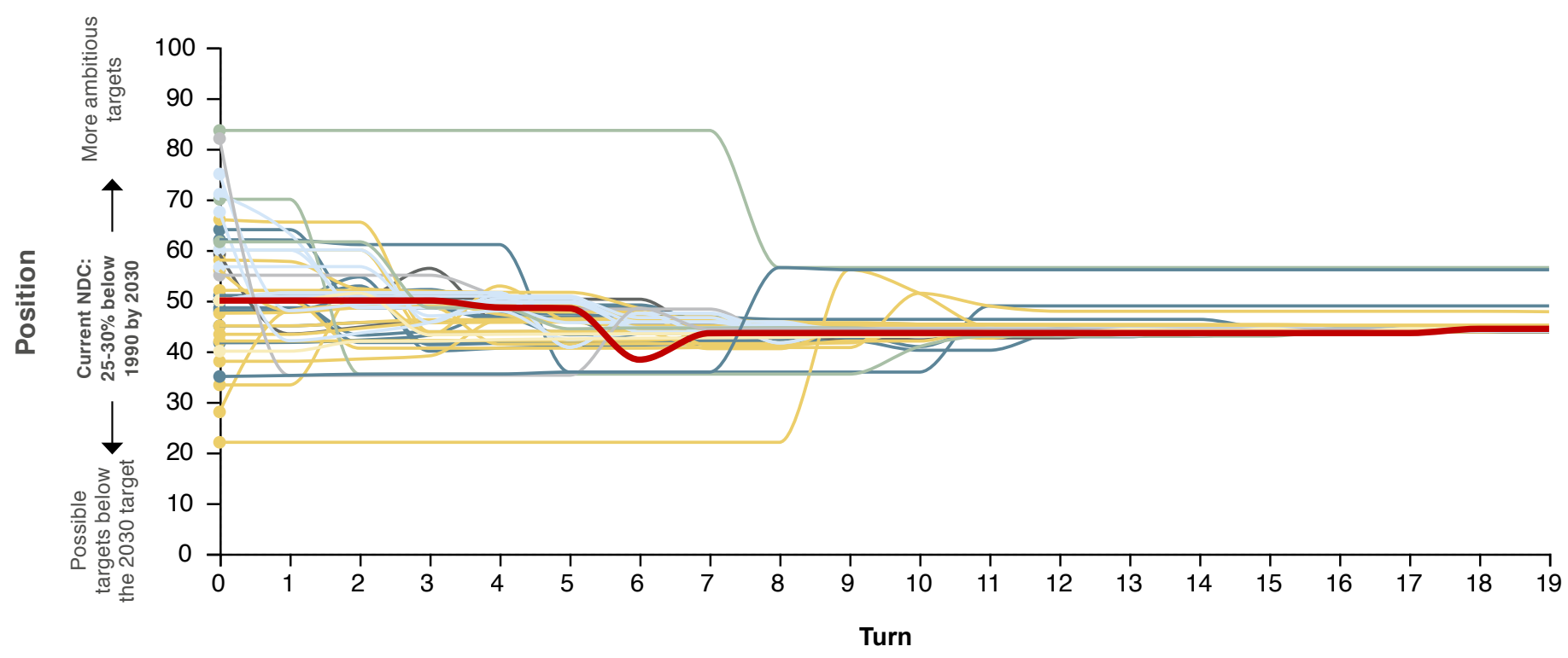

Source: KAPSARC KTAB analysis.

Figure 4 depicts a dynamic view of how the actors' positions change over time (measured in turns) based on the KTAB simulation. This provides a view on changing positions and coalitions over the course of the simulation, as actors bargain amongst one another. Turn 0 reflects the initial conditions based on the data collected from experts, whereas the subsequent turns are simulated results from the KTAB SMP module and derived without expert commentary. An actor shifts positions from one turn to the next, once they have been influenced by another actor and see a change in position as being in their best interest. Actors are continuously balancing their desire to achieve the highest degree of consensus they believe possible with their objective of achieving an outcome close to their preferred position on the scale.

The range of positions from 0 to 100 is shown on the vertical axis. Turns are shown on the horizontal axis. Actors are color-coded by group. Further details on this and all other simulations are available in the form of PowerPoint presentations on the KTAB project website, www.ktab.software. The simulation eventually leads to a narrowed range of positions which reflect a politically plausible outcome of the CDMP.

As shown in Figure 4, Rosatom shifts to a more moderate position, closer to the developing consensus, during the seventh turn in response to pressure from Sergei Ivanov. SUEK also joins the moderate position occupied by Rosatom and Ivanov during the eighth turn, again following pressure from Ivanov.

The final agreed consensus, supporting the current INDC, begins to clearly form by the ninth turn, aside from Ivanov and Rosatom advocating a position in favor of a slightly more ambitious commitment. This reaffirms the inference from Figure 3 that the emerging political will in Russia supports maintaining its current climate targets. 


\section{Recent Developments}

s highlighted above, the Ministry of

Economic Development introduced a draft

bill in late 2018 on the state regulation of emissions and GHGs. The bill intends to set a framework toward reducing GHG emissions while maintaining sustainable economic development. Through the bill, the government is "proposing a permit system for direct emissions of GHG; economic mechanisms to regulate emissions and absorption, including mechanisms of transfer and trading of units of emissions and absorption; and taxation privileges" (Grigoryan 2019).

While seemingly an elementary measure when compared with its European counterparts, given that specific targets for distinct sectors are not included, the bill signifies an important step for Russia, in spite of the bill not mentioning the Paris Agreement. It would set a new legal norm within Russian legislation by "providing $\mathrm{CO}_{2}$ and other greenhouse gases with legal status" (Sauer and Collett-White
2019). However, as signaled by the KTAB simulation, the bill and its proposed reforms have been met with considerable opposition. The opposition has come particularly from the Russian energy ministry and the RSPP. The RSPP even introduced a distinct version of the bill excluding emissions quotas and charges for exceeding targets.

The debate has even prompted President Putin to address the issue by urging members of the RSPP congress to overcome their differences and assist in Russia's sustainable development. Despite statements from the president, observers largely expect that fierce opposition to the bill will ultimately lead to its weakening. The bill was expected to be passed in June 2019, with enforcement taking effect in 2025. However, this is yet to happen. The bill has not yet officially been sent to the government for consideration, as the Institution of Regulatory Impact Assessment is currently evaluating it. 


\section{Conclusion}

E missions in Russia have dramatically fallen following its economic shift away from Soviet-style industrial production after the collapse of the Soviet Union. Thus, not only is it almost guaranteed that Russia will meet its INDC by 2030, but Russia may even increase its emissions while still meeting its 2030 target (Makarov, Chen and Paltsev 2017). While there are many reasons why Russia does not want to push for a more ambitious INDC, at its core is the lack of a broad economic incentive for more ambitious targets, in addition to the lack of strong political drivers, suggesting that there is little scope for a more ambitious INDC. The general feeling in Russia is that it has already done its part for the environment in the past and that the rest of the world needs to catch up. Furthermore, Russia continues to stress that its large forests provide a major contribution by capturing carbon and acting as a carbon sink, which benefits the rest of the world (particularly Europe and Asia).

While climate change is indeed an economic and environmental concern, the domestic political context in Russia, as simulated by the KTAB methodology, indicates little support for any strengthening of Russia's current INDC. When focusing on the most influential actors in Russia, who are capable of playing a large role in steering the discourse, it is clear from the simulation that the president is not directly involved or particularly concerned about this issue. It appears that his representative on the issue, Sergei Ivanov, is firmly in the driver's position. In terms of ratifying the Paris Agreement, Ivanov has stated that full accounting of Russian forests is a prerequisite, which is expected to be completed in 2020 .
Overall, the Russian government does not give much attention to the issue of climate change. This became evident in 2018 when the two of the most experienced government officials were replaced: Alexander Bedtritsky (former president of the World Meteorological Organization and former advisor to the Russian president and Russia's Special Envoy for Climate); and a Ministry of Foreign Affairs official, described as an expert in climate negotiations. The new advisor on climate is Ruslan Edelgeriyev, a former prime minister of the Chechen Republic who, according to experts, did not have a substantial background on climate issues when appointed. Indicative of the priority attached by the Russian government to climate issues, as of 2019 climate change is not yet the responsibility of any official Russian governmental agency.

In the past, Russia has used climate change and its participation in international treaties as a strategic bargaining chip to be played in broader geopolitical and economic relations. While there is hope for change from the recently introduced draft legislation, staunch resistance from within both government and industry have led to uncertainty. Considering climate action on its own, many believe there is little chance that Russia will prioritize more ambitious measures. Without economic incentives, such as handicaps that Russian exporters may face from not acceptably recording emissions, it is likely that little will change. However, the draft bill, which may end up being stripped back to merely establishing guidelines for reporting emissions, could very well be a slight indicator of change on the horizon. 


\section{References}

Aslund, Anders. 1999. "Why Has Russia's Economic Transformation Been So Arduous?" Carnegie Endowment for International Peace, April 28. https:// carnegieendowment.org/1999/04/28/why-has-russia-seconomic-transformation-been-so-arduous-pub-201.

Astrasheuskaya, Nastassia. 2012. "Russia Will Not Cut Emissions under Extended Kyoto Climate Pact." Reuters, September 13. www.reuters.com/article/us-russia-kyoto/ russia-will-not-cut-emissions-under-extended-kyotoclimate-pact-idUSBRE88C0QZ20120913.

Climate Action Tracker. 2019. "Russian Federation". Accessed November 1, 2018. https://climateactiontracker. org/countries/russian-federation/.

Climate Action Tracker. 2018. "Paris Tango. Climate Action so Far in 2018: Individual Countries Step Forward, Others Backward, Risking Stranded Coal Assets." May 3. https://climateactiontracker.org/publications/paris-tangoclimate-action-so-far-2018-individual-countries-stepforward-others-backward-risking-stranded-coal-assets/.

Davydova, Angelina. 2018. "Climate Will Wait - Russia Is Not in a Hurry to Ratify the Paris Agreement." Kommersant, May 12. www.kommersant.ru/doc/3627656.

Davydova, Angelina. 2015. "Why Russia's Forests Must Be Protected." Presentation at World Economic Forum, Davos-Klosters, January 16. www.weforum.org/ agenda/2015/01/why-russias-forests-must-be-protected/.

Davydova, Angelina, and Dmitry Kozlov. 2018. "Emission Control Concept Has Changed - Control of Greenhouse Gases Will Do without 'Carbon Prices.' Kommersant, March 22. www.kommersant.ru/doc/3579808.

Government of Russia. n.d. "On State Regulation of Greenhouse Gas Emissions and on Amendments to Certain Legislative Acts of the Russian Federation." Federal Portal of Projects of Regulatory Legal Acts. Accessed March 19, 2019. https://regulation.gov.ru/ projects/List/AdvancedSearch\#search=регулировании выбросов парниковых газов\&nра=86521.

Grigoryan, Astghik. 2019. "Russia: Government Introduces Bill to Regulate Greenhouse Gas Emissions and Absorption." The Library of Congress. May 7. www.loc.gov/law/foreign-news/article/russia-governmentintroduces-bill-to-regulate-greenhouse-gas-emissionsand-absorptions/.
Gutbrod, Max, and Maxim Kalanin. 2018. "Draft Law Gives a Sense of Direction on Russian Climate Policy." Baker McKenzie. December 27. www.bakermckenzie.com/en/insight/ publications/2018/12/draft-law-gives-a-sense-of-direction.

Henry, Laura A., and Lisa McIntosh Sundstrom. 2007. "Russia and the Kyoto Protocol: Seeking an Alignment of Interests and Image." Global Environmental Politics 7 (4). https://politics.sites.olt.ubc.ca/files/2017/01/GEP-0704Henry-Sundstrom.pdf.

Howarth, Nicholas, and Andrew Foxall. 2012. "More than Hot Air: The Economics and Politics of Climate Change in Russia." In Feeling the Heat: The Politics of Climate Policy in Rapidly Industrializing Countries. Basingstoke: Palgrave Macmillan. DOI: https://doi. org/10.1057/9780230374973_8

Kremlin. 2019. "Vladimir Putin Speaks at Plenary Session of Congress of Russian Union of Industrialists and Entrepreneurs." March 14. http://kremlin.ru/events/ president/news/60065

Makarov, Igor. 2018. "Potential of Russia to Fulfil its INDC and Elite Moods on the Paris Agreement." Presentation at KAPSARC Workshop, the Political Feasibility of Implementing and Enhancing Nationally Determined Contributions (NDCs). Paris, France. October 3, 2018.

Makarov, Igor, Y.-H. Henry Chen, and Sergey Paltsev. 2017. "Finding Itself in the Post-Paris World: Russia in the New Global Energy Landscape." MIT Joint Program on the Science and Policy of Global Change. December.

Ministry of Foreign Affairs of the Russian Federation. 2017. "Foreign Minister Sergey Lavrov's Interview with the Mexican Newspaper Excélsior." November 17. www.mid.ru/en/press_service/minister_speeches/-/ asset_publisher/7OvQR5KJWVmR/content/id/2953146.

Ministry of Foreign Affairs of the Russian Federation. 2015. "Remarks by Foreign Minister Sergey Lavrov at the UN Summit for the Adoption of the Post-2015 Development Agenda, New York." News release, September 27. www.mid.ru/en/vistupleniya_ministra/-/ asset_publisher/MCZ7HQuMdqBY/content/id/1794073.

RIA Novosti. 2019. "Ivanov States When Russia Will Ratify the Paris Climate Agreement." March 12. https://ria.ru/20190312/1551727972.html. 
Permanent Mission of the Russian Federation to the United Nations (RussiaUN). 2016. "Statement by H.E. Mr. Alexander Khloponin, Deputy Prime Minister of the Russian Federation at the Signature Ceremony for the Paris Agreement." News release, April 22.

http://russiaun.ru/en/news/ga_pas.

Sauer, Natalie, and Richard Collett-White. 2019. "Russia Floats First Law to Regulate $\mathrm{CO}_{2}$ Emissions." Climate Change News, March 22. www.climatechangenews.com/2019/03/22/ russia-floats-first-law-regulate-carbon-emissions/.

Sberbank. 2011. "Gazette: Lost Billions." News release, October 3. www.sberbank.ru/ru/press_center/smibank/ article?newsID=11013787-1-1\&blockID=11003755®ionID= $77 \&$ lang=ru.

Suvorova, Natalia. 2019. "Russia Considers Capand-Trade Greenhouse Gas Law." Bloomberg Environment, January 24. https://news. bloombergenvironment.com/environment-and-energy/ russia-considers-cap-and-trade-greenhouse-gas-law.

United Company RUSAL. 2018. "Aluminum Crafted by Green Energy." March 2018. https://rusal.ru/upload/ iblock/9be/RUSAL_general_eng_March 2018.pdf.
United Nations. 2016. "List of Parties that Signed the Paris Agreement on 22 April." High-Level Signature Ceremony for the Paris Agreement. April 22. www.un.org/sustainabledevelopment/wp-content/ uploads/2016/04/22-April-2016-list.pdf.

UNFCCC Secretariat. n.d. "Kyoto Protocol - Targets for the First Commitment Period." Accessed October 15, 2018. https://unfccc.int/process/the-kyoto-protocol.

Walsh, Nick Paton. 2004. "Russian Vote Saves Kyoto Protocol." The Guardian, October 23, 2004. www. theguardian.com/world/2004/oct/23/society.russia.

Wise, Ben, Leo Lester and Brian Efird. 2015a. "An Introduction to the KAPSARC Toolkit for Behavioral Analysis (KTAB) Using One-Dimensional Spatial Models." KAPSARC Discussion Paper. May. KS-1517-DP011A.

Wise, Ben, Leo Lester and Brian Efird. 2015b. "Multidimensional Bargaining Using KTAB." KAPSARC Discussion Paper. November. KS-1524-DP018A. 
Notes

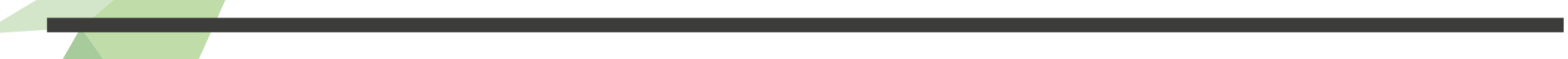




\section{Notes}




\section{Appendix 1: Baseline dataset: Weighted average of expert inputs}

\begin{tabular}{|c|c|c|c|c|}
\hline Actor & Group & Position & Influence & Salience \\
\hline Vladimir Putin & President & 50 & 100 & 13.8 \\
\hline Andrei Belousov (Assistant to President) & Executive Branch & 50 & 37 & 6.8 \\
\hline Sergey Glazyev (Economic Advisor) & Executive Branch & 41.67 & 23.75 & 8 \\
\hline Dmitry Medvedev (Prime Minister) & Executive Branch & 50 & 59 & 21.8 \\
\hline $\begin{array}{l}\text { Sergei Ivanov (Special Representative of the } \\
\text { President) }\end{array}$ & Executive Branch & 35 & 50 & 90 \\
\hline $\begin{array}{l}\text { Ruslan Edelgeriyev (Special Advisor on Climate } \\
\text { to Vladimir Putin) }\end{array}$ & Executive Branch & 50 & 18.33 & 77 \\
\hline Alexander Novak (Minister of Energy) & Executive Branch & 48.57 & 44 & 32.8 \\
\hline $\begin{array}{l}\text { Maxim Oreshkin (Minister for Economic } \\
\text { Development) }\end{array}$ & Executive Branch & 50 & 44 & 25.8 \\
\hline $\begin{array}{l}\text { Maria Petrova (Expert in Ministry for Economic } \\
\text { Development) }\end{array}$ & Executive Branch & 64 & 1 & 100 \\
\hline $\begin{array}{l}\text { Anton Siluanov (First Deputy Prime Minister } \\
\text { and Minister of Finance) }\end{array}$ & Executive Branch & 48 & 42 & 12.2 \\
\hline $\begin{array}{l}\text { Alexei Kudrin (Economic Advisor and Chairman } \\
\text { of the Accounts Chamber) }\end{array}$ & Executive Branch & 51 & 37 & 14.8 \\
\hline Minister of Natural Resources and Environment & Executive Branch & 50 & 43 & 54.8 \\
\hline $\begin{array}{l}\text { Larissa Korepanova (Deputy Director of } \\
\text { Department of Environmental Monitoring) }\end{array}$ & Executive Branch & 62 & 10.5 & 100 \\
\hline Sergey Lavrov (Foreign Minister) & Executive Branch & 50 & 34.4 & 12.8 \\
\hline Denis Manturov (Minister of Industry) & Executive Branch & 45 & 40 & 20.5 \\
\hline $\begin{array}{l}\text { Nikolay Patrushev (Secretary of the Security } \\
\text { Council) }\end{array}$ & Executive Branch & 50 & 38 & 14.4 \\
\hline $\begin{array}{l}\text { Valentina Matviyenko (Chairwoman of the } \\
\text { Federation Council) }\end{array}$ & Federal Assembly & 50 & 28 & 6.8 \\
\hline $\begin{array}{l}\text { Nikolay Fyodorov (First Deputy Chairman of the } \\
\text { Federation Council) }\end{array}$ & Federal Assembly & 50 & 11.67 & 10 \\
\hline $\begin{array}{l}\text { Committee on Natural Resources and } \\
\text { Environmental Protection }\end{array}$ & Federal Assembly & 50 & 13 & 34 \\
\hline $\begin{array}{l}\text { Elvira Nabiullina (Head of the Central Bank of } \\
\text { Russia) }\end{array}$ & Federal Assembly & 50 & 31.25 & 6.5 \\
\hline German Gref (Sberbank CEO) & Federal Assembly & 59.17 & 37 & 15.8 \\
\hline Vnesheconombank & Federal Assembly & 50 & 37 & 18 \\
\hline $\begin{array}{l}\text { Vyacheslav Volodin (Chairman of the State } \\
\text { Duma) }\end{array}$ & Federal Assembly & 50 & 16.4 & 6.4 \\
\hline $\begin{array}{l}\text { Pavel Zavalniy (Deputy Chairman of the State } \\
\text { Duma Committee on Energy) }\end{array}$ & Federal Assembly & 50 & 18.75 & 41 \\
\hline Gazprom & Energy Companies & 50 & 50 & 43.8 \\
\hline Vladimir Bogdanov (Surgutneftegas President) & Energy Companies & 38 & 35 & 18 \\
\hline Igor Sechin (Rosneft CEO) & Energy Companies & 33.33 & 55 & 18.8 \\
\hline Vagit Alikperov (Lukoil President) & Energy Companies & 43.33 & 35 & 16.8 \\
\hline Leonid Mikhelson (Novatek CEO) & Energy Companies & 56 & 33 & 20.8 \\
\hline Arkady Rotenberg (Stroytransgas) & Energy Companies & 47.5 & 38.75 & 5.25 \\
\hline Oleg Deripaska & Energy Companies & 58 & 35 & 33.75 \\
\hline
\end{tabular}




\begin{tabular}{|c|c|c|c|c|}
\hline Actor & Group & Position & Influence & Salience \\
\hline Rusal & Energy Companies & 66 & 25 & 33.75 \\
\hline NLMK & Energy Companies & 45 & 29 & 21.2 \\
\hline Other steel producers & Energy Companies & 42 & 25 & 36.25 \\
\hline SUEK & Energy Companies & 22 & 29 & 50.8 \\
\hline InterRao & Energy Companies & 52 & 16.25 & 30 \\
\hline SGK & Energy Companies & 28 & 11.5 & 32.5 \\
\hline Enel Russia & Energy Companies & 60 & 1 & 10 \\
\hline ExxonMobil & International Companies & 50 & 1 & 10 \\
\hline BP & International Companies & 50 & 1 & 7.5 \\
\hline Shell & International Companies & 67.5 & 2 & 8.33 \\
\hline Total & International Companies & 56.67 & 3 & 15 \\
\hline Wintershall & International Companies & 75 & 3 & 7.5 \\
\hline Uniper & International Companies & 60 & 1 & 6.5 \\
\hline ENGIE & International Companies & 60 & 1 & 7.5 \\
\hline OMV Group & International Companies & 50 & 1 & 7.5 \\
\hline RWE & International Companies & 71 & 3.5 & 39 \\
\hline Fortum (RE) & $\begin{array}{l}\text { Renewable Energy } \\
\text { Companies }\end{array}$ & 61.6 & 10.67 & 21.67 \\
\hline ROSATOM & $\begin{array}{l}\text { Renewable Energy } \\
\text { Companies }\end{array}$ & 83.6 & 31.67 & 63.67 \\
\hline Rusnano & $\begin{array}{l}\text { Renewable Energy } \\
\text { Companies }\end{array}$ & 70 & 25 & 52 \\
\hline Climate advocates (Greenpeace, WWF, etc.) & Climate Organizations & 82 & 6.67 & 96.67 \\
\hline Russian Partnership for Climate Protection & Climate Organizations & 55 & 5.5 & 42.5 \\
\hline Business Russia & Businesses & 40 & 20 & 20 \\
\hline $\begin{array}{l}\text { Union of Industrialists and Entrepreneurs } \\
\text { (RSPP) }\end{array}$ & Businesses & 50 & 30 & 20 \\
\hline
\end{tabular}




\section{About the Authors}

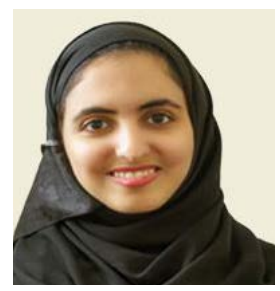

\section{Imtenan Al-Mubarak}

Imtenan is a senior research associate in KAPSARC's Policy and Decision Science program with years of experience in the industry and the research. She is also leading the research strategic project management activities. Imtenan holds a Master's degree with distinction in Software engineering and leadership from DePaul University, Chicago, USA. She is a Future Energy Leader at World Energy Council in London.

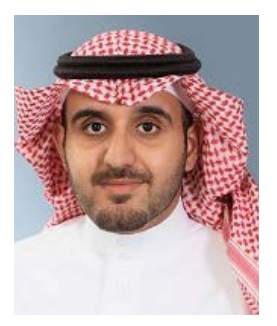

\section{Saleh AI Muhanna}

Saleh is a senior research analyst in the Policy and Decision Science program. His interests lie in geopolitical research, international agreements and international trade. Saleh holds a master's degree in international commerce and policy from George Mason University and a B.S. degree in economics from Pennsylvania State University.

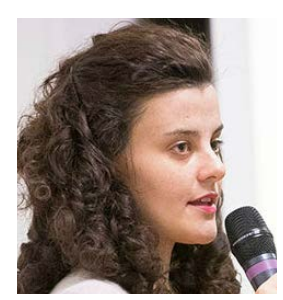

\section{Zlata Sergeeva}

Junior Analyst, SKOLKOVO Energy Centre.

Zlata focuses on the political aspects of global energy. She regularly takes part in Russian and international scientific conferences, is the founder and chairman of the Higher School of Economics' Geo-Energy Politics Club and the winner of several Russian and international competitions for young scientists. She has completed a number of domestic and foreign degree programs, in particular at MGIMO, the Paris Institute of Political Studies (Sciences Po) and the University of North Carolina in the United States. She is currently completing her studies at the Higher School of Economics, specializing in Political Analysis.

\section{About the Project}

This project evaluates the political feasibility for signatories of the Paris Agreement under the United Nations Framework Convention on Climate Change (UNFCCC) to effectively implement and iteratively improve their nationally determined contributions (NDCs), such that the rise of global temperature is limited to well below $2^{\circ} \mathrm{C}$ above pre-industrial levels. This includes five 'deep dive' studies for each of the world's top five emitters: China, the EU, India, Russia and the U.S.. Additionally, the project focuses on a global, geopolitical perspective for this question, based on non-expert data. 
INAPSARC

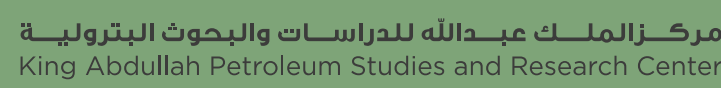

www.kapsarc.org 